\title{
Relationships between environmental governance and water quality in a growing metropolitan area of the Pacific Northwest, USA
}

\author{
H. Chang ${ }^{1}$, P. Thiers ${ }^{2}$, N. R. Netusil ${ }^{3}$, J. A. Yeakley ${ }^{4}$, G. Rollwagen-Bollens ${ }^{5}$, S. M. Bollens ${ }^{5}$, and S. Singh ${ }^{1}$ \\ ${ }^{1}$ Department of Geography, Portland State University, Portland, OR, USA \\ ${ }^{2}$ School of Politics, Philosophy and Public Affairs, Washington State University, Vancouver, WA, USA \\ ${ }^{3}$ Department of Economics, Reed College, Portland, OR, USA \\ ${ }^{4}$ School of the Environment, Portland State University, Portland, OR, USA \\ ${ }^{5}$ School of the Environment, Washington State University, Vancouver, WA, USA
}

Correspondence to: H. Chang (changh@pdx.edu)

Received: 25 May 2013 - Published in Hydrol. Earth Syst. Sci. Discuss.: 11 June 2013

Revised: 29 January 2014 - Accepted: 25 February 2014 - Published: 9 April 2014

\begin{abstract}
We investigate relationships between environmental governance and water quality in two adjacent growing metropolitan areas in the western US. While the Portland, Oregon and Vancouver, Washington metro areas share many common biophysical characteristics, they have different land development histories and water governance structures, providing a unique opportunity for examining how differences in governance might affect environmental quality. We conceptualize possible linkages in which water quality influences governance directly, using monitoring efforts as a metric, and indirectly by using the change in the sale price of single-family residential properties. Governance may then influence water quality directly through riparian restoration resulting from monitoring results and indirectly through land use policy. We investigate evidence to substantiate these linkages. Our results showed that changes in monitoring regimes and land development patterns differed in response to differences in growth management policy and environmental governance systems. Our results also showed similarities in environmental quality responses to varying governance systems. For example, we found that sales prices responded positively to improved water quality (e.g., increases in DO and reductions in bacteria counts) in both cities. Furthermore, riparian restoration efforts improved over time for both cities, indicating the positive effect of governance on this land-based resource that may result in improved water quality. However, as of yet, there were no substantial differences across study areas in water temperature over time, despite an expansion of these urban areas of more than $20 \%$ over 24 years.
\end{abstract}

The mechanisms by which water quality was maintained was similar in the sense that both cities benefited from riparian restoration, but different in the sense that Portland benefited indirectly from land use policy. A combination of long-term legacy effects of land development, and a relatively short history of riparian restoration in both the Portland and Vancouver regions, may have masked any subtle differences between study areas. An alternative explanation is that both cities exhibited combinations of positive indirect and direct water quality governance that resulted in maintenance of water quality in the face of increased urban growth. These findings suggest that a much longer-term water quality monitoring effort is needed to identify the effectiveness of alternative land development and water governance policies.

\section{Introduction}

The dynamic relationship between environmental quality and local governance is increasingly conceptualized through a coupled human and natural systems (CHANS) approach (Liu et al., 2007; McConnell et al., 2011). While this approach holds promise for understanding dynamic relationships over time, an important theoretical and empirical question is through what pathways and to what extent biophysical systems and social systems are coupled. Empirical observation and theoretical conceptualization are needed to begin to understand the processes and feedbacks that link these systems. 
This study considers multiple pathways between governance and environmental quality by asking how scientific knowledge and human perceptions about local water quality enter the policy process and how policy actions in turn affect local water quality over time in urban areas. We consider two pathways by which water quality information and the perception of water quality might enter the human system: water quality monitoring and the sale price of single-family residential properties. We consider riparian corridor restoration projects and land use policy as government actions that might impact water quality.

We investigate interactions between water quality and environmental governance in a single metropolitan area with different forms of governance spanning state to local scales. In the Portland-Vancouver metropolitan area in the Pacific Northwest of the United States, a common biophysical landscape spans a state border, marked by the Columbia River. While the two cities are subject to common federal laws (such as the US Clean Water Act), those laws are implemented by different state agencies within the context of differing regional and local governance structures. We chose a single stream and surrounding watershed in each city (Johnson Creek, Portland, OR and Burnt Bridge Creek, Vancouver, WA) as specific ecosystems for comparison across the two state and local governments. This contrast provides a relatively unique opportunity to investigate how differing governance systems collect and interpret information about the biophysical system and how differing environmental governance systems impact the biophysical system over time.

\section{Conceptual framework and research questions}

Increasingly, the Coupled Human and Natural Systems (CHANS) (Liu et al., 2007) approach has been used to understand the complex interactions between society and nature in urban areas. For example, Chowdhury et al. (2011) explained the evolution of urban residential landscape across four US cities using the CHANS framework. However, few authors have examined the complex multiple interactions and possible feedbacks among landscape patterns, water quality, environmental governance, and property sale prices. While our study does not attempt to model all complex linkages among different components of the coupled system, we seek to identify possible linkages among major components of the coupled human and water systems as reflected in the relationship between water quality and environmental governance. As such, our study contributes to the expanding body of literature in urban ecosystem studies using the CHANS framework. It is one of the first attempts to investigate the linkages among environmental governance, riparian conditions, land development patterns, and water quality in two adjacent urban areas. Furthermore, with an explicit engagement of water quality managers and other governance stakeholders, our study contributes to the nascent field of sociohydrology, an interdisciplinary field studying the dynamic interactions and feedbacks between water and people (Pataki et al., 2011; Sivapalan et al., 2012).

We focus on the following specific research questions under the overarching theme of "Does governance matter to water quality?"

1. Does monitoring effort differ as a function of governance between the two cities?

2. Do riparian conditions differ between the two watersheds and are they associated with indicators of water quality?

3. Do land development patterns differ between the two watersheds and do they correlate with water quality?

4. Is there a relationship between water quality and the sale price of properties and, if so, does that relationship vary between the two watersheds?

Questions (1) and (2) examine the potential for direct and intentional pathways between water quality and water governance. If such pathways are found, one might hypothesize a straightforward coupling of biophysical landscapes and environmental governance in which local governments collect scientific information about the ecosystem in order to take intentional, effective policy action.

Questions (3) and (4) examine indirect and unintentional pathways between water quality and environmental governance. If present, these pathways point toward a much more complex coupling in which the relationship between governance and water quality is primarily an unintended consequence of other interactions between natural and human systems. Both direct and indirect pathways might matter, but their relative significance might differ under differing forms of governance.

To visualize the multiple and complex relationships between the biophysical and human/social domains in our system, we developed a conceptual model (Fig. 1). The model exhibits a spectrum of possible linkages between water quality and governance. We are primarily interested in two pathways that might operate very differently: intentional or direct connectivity between water quality and environmental governance are represented by thick solid arrows in Fig. 1, while those that are less direct or less intentional are represented by dashed arrows. This is intended to capture the likelihood that not all pathways by which water quality characteristics eventually impact governance are direct and not all policy actions that eventually impact water quality are intended to do so.

In this paper, we only examine four possible linkages (1) the impact of the governance system on water quality monitoring; (2) the impact of changes in riparian conditions on water quality change; (3) the relationship between land cover change and water quality change; and (4) the relationship between water quality and a property's sale price. Each 


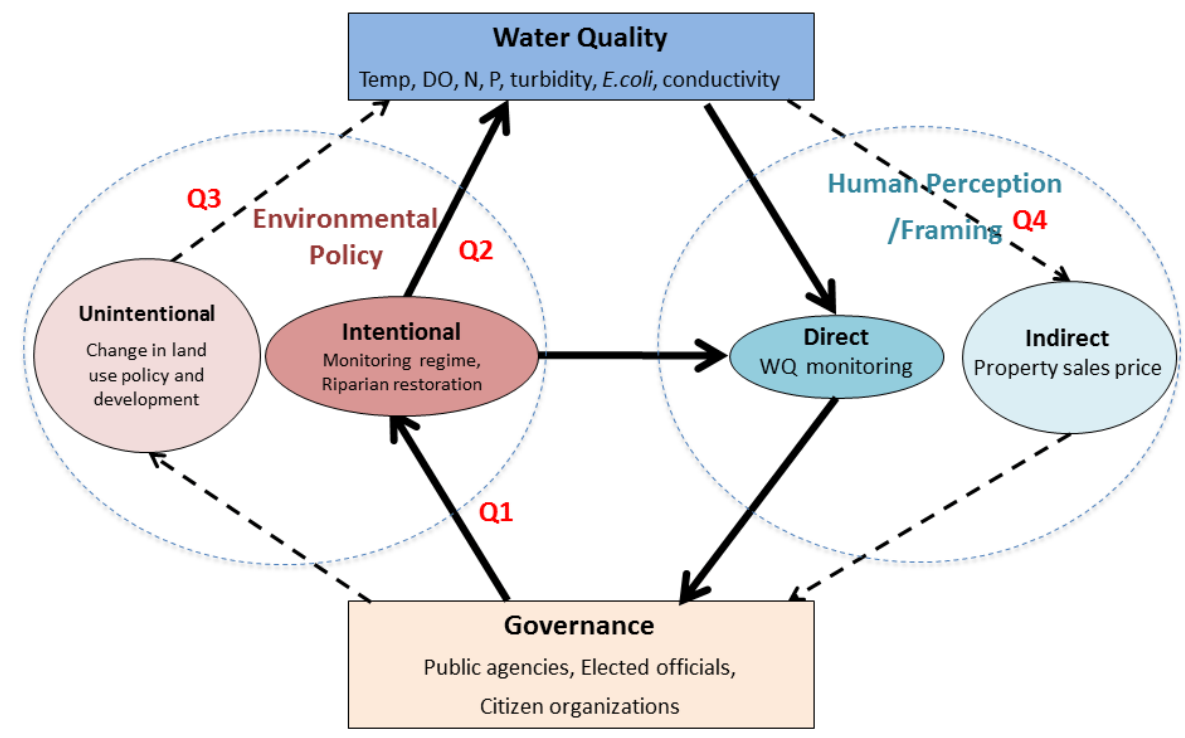

$\longrightarrow$ Represents direct and/or intentional linkage related to water quality (Water governance)
$\longrightarrow$ - Represents indirect and/or unintentional linkage to water quality (Environmental governance)

Fig. 1. Coupled natural and human systems framework for understanding the coupled environmental governance and water quality.

of these is an example of direct $(1,2)$ or indirect $(3,4)$ pathways by which water quality characteristics might reach institutions of government and government policy might impact water quality. Water quality monitoring generates scientific information that would seem to be of direct relevance to water quality management. Property sale prices are generated through economic rather than scientific behavior and represent an indirect pathway by which human perception and valuation (including perception and valuation of local water quality) might reach the attention of policymakers and government managers (Fischel, 2005). Riparian zone restoration and protection and land use policy are examples of policies that might be expected to impact water quality. While riparian restoration projects may be undertaken for a number of reasons (e.g., improved feeding habitat for fish and wildlife), improvement of water quality is a common intention of such policies. Conversely, while land use policy has obvious implications for water quality, both the preservation of farmland and the avoidance of the costs of government services due to sprawl are much more frequently cited as the primary goals of land use regulation (Abbott et al., 1994). Our conceptual model lays out some of the relationships that are important to examine, and our initial data analyses identify and provide insights into some forms of sociohydrology that might exist in this metropolitan area.

\section{Materials and methods}

\subsection{Study area}

Our study area is located in the Portland-Vancouver Combined Metropolitan Statistical Area (MSA). This MSA exhibits a typical marine west coast climate, with cool, wet winter and mild, dry summers. The area receives approximately $1000 \mathrm{~mm}$ of rain annually and more than half of the rainwater becomes runoff (Chang, 2007). The Portland-Vancouver MSA, home to more than 2 million residents, is one of the fastest growing metropolitan areas in the US, growing by more than $25 \%$ between 1990 and 2010 (US Census 2010). Some of this population growth has occurred at the expense of converting agricultural or forested lands to urban residential lands (Fig. 2). According to the US Geological Survey national land cover classification, urban land cover increased from 58 to $83 \%$ in Portland and from 52 to $86 \%$ in Vancouver between 1992 and 2006. Previous studies on water quality in the Portland-Vancouver MSA report that the spatial and temporal variations of water quality are associated with land cover, building density, and topographic variables (Boeder and Chang, 2008; Pratt and Chang, 2012).

While urban growth boundaries in both parts of the metropolitan area have affected the location of new development and conserved areas of forest and agricultural lands (Hoyer and Chang, 2014), these effects vary between the Oregon and Washington counties that are included in our study area. This is likely due to different land use planning histories and associated development patterns between the two states. Oregon's process started with the Land Use Act in 
(a) 1992

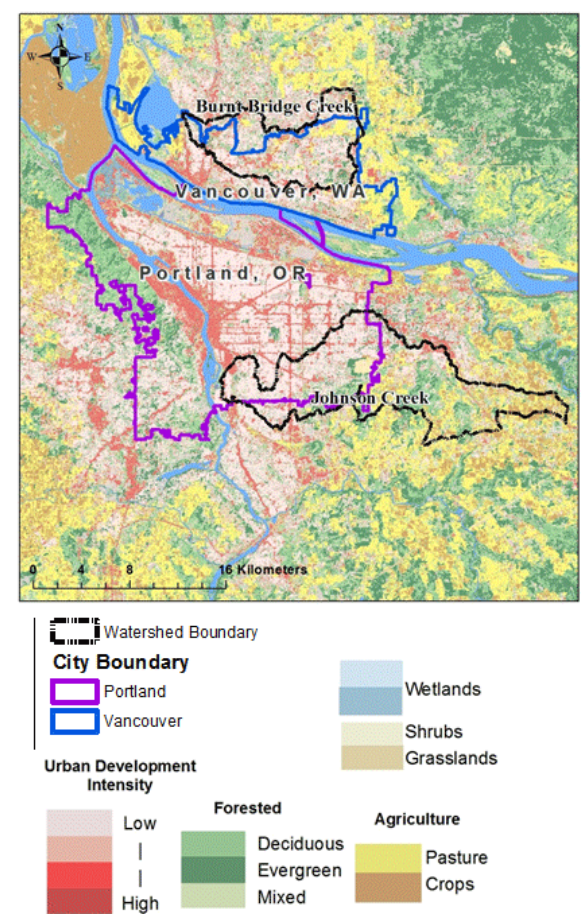

(b) 2006

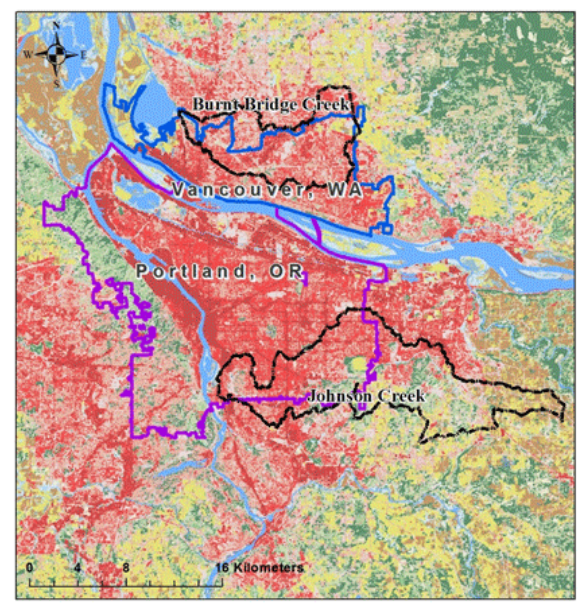

Fig. 2. Study watersheds boundary, city boundary and land cover classes in the study area, 1992-2006.

1973, while Clark County in Washington implemented land use planning in 1990 with the state's adoption of the Growth Management Act. Oregon's Land Use Act is unique in that it limits growth outside of urban growth boundaries while it promotes in-fill development or redevelopment of existing developed areas with higher density. On the other hand, under Washington's Growth Management Act, the great supply of undeveloped land within the current urban growth boundary promotes sparse development.

Because the Portland-Vancouver MSA covers a wide geographical area, we chose two representative creeks - Burnt Bridge Creek, located in the city of Vancouver, Washington, and Johnson Creek, located primarily within the city of Portland, Oregon - for our case study. These two creeks were chosen because (1) they have undergone significant land cover change in the past two decades (Burnt Bridge Creek in Washington has been developed rapidly and at relatively low density, while new development in the Johnson Creek area in Oregon has been limited with denser development); (2) water quality has been a concern and both creeks are listed as impaired streams under article 303(d) of the Clean Water Act; and (3) both creeks have been the target of state and local policy intervention.

\subsection{Data and methods}

Water quality data were obtained from multiple agencies: US Geological Survey, Oregon Department of
Environmental Quality, the City of Portland, Washington Department of Ecology, and Clark County, WA. We selected stream temperature as an appropriate indicator of stream status since it can not only represent many biophysical conditions of streams and nearby stream zones (Allen, 1995; Caissie, 2006; Yeakley, 2014), but also can influence the perception of environmental quality as reflected in the sales prices of homes. For instance, stream temperature was identified as a major concern in the 303(d) listings for both creeks. High stream temperature is typically associated with disturbed riparian conditions such as low vegetation cover and low groundwater flow inputs (Chang and Lawler, 2011; Chang and Psaris, 2013). Warmer stream temperatures accelerate in-stream biogeochemical conditions, lowering dissolved oxygen concentrations and precipitating algal blooms (Lee et al., 2014). Increases in E. coli concentrations and lack of clarity are of great concern for human and aquatic health, affecting aesthetic and cultural values of streams. For example, in Johnson Creek, restoration efforts have been focused on improving stream temperature by planting more trees, which provide habitat for cold-adapted fish species to migrate upstream (Johnson Creek Watershed Council, 2013). Additionally, stream temperature data have been collected more frequently than other water quality data in our study areas. Finally, a wildlife biologist from Metro interviewed in this study identified stream temperature as the best indicator for summarizing science for policymakers in this metropoli$\tan$ area. 
We used only water quality data collected by governmental agencies because our interviews indicated that water quality data collected by citizens and non-governmental organizations are not typically incorporated into government analysis nor considered influential by government staff. While governmental monitoring is only a part of the very broad concept of water governance, this is an appropriate and tractable variable from which to begin to look for and describe interactions within the coupled system. Monitoring is an intentional attempt by some of the social actors in the system to understand the biophysical status and responses of the system to management actions. It is also an opportunity to observe several components of water governance across these two different governance systems.

Land cover data were acquired from the USGS national land cover data set (USGS, 2012) at $30 \mathrm{~m}$ spatial resolution for two years - 1992 and 2006 - representing snapshots of land cover change. We used ArcGIS 10.1 to derive the distribution of land cover for each year by watershed. We used a two sample means t-test to identify if mean stream temperatures differed between the two periods (1990s vs. 2000s) for each study watershed.

Changes in riparian areas between 1990 and 2008 were estimated based on aerial photo analysis following the methods described elsewhere (Ozawa and Yeakley, 2007; Yeakley et al., 2012). Aerial photos were analyzed at $0.3 \mathrm{~m}$ resolution for all permanent streams within the 1990 city boundaries of Portland and Vancouver. Vegetation cover was classified as either "woody" (i.e., trees and shrubs) or "unmanaged" (e.g., greenspaces and unmanaged vacant lots), and as either in a contiguous patch connected to the stream ("adjacent") or just existing within a specific buffer width from the stream. Buffer widths analyzed included distances from the top of the stream bank spanning from 7.5 to $100 \mathrm{~m}$. The close-in buffer widths represent areas that are most amenable to policy and management practices intended to conserve riparian buffers, while buffer widths at $100 \mathrm{~m}$ are more representative of general development pressure.

Single-family residential property sale data for 20052007 were obtained from the Multnomah County, OR, and Clark County, WA, Assessors. We used the hedonic price method, a statistical technique, to examine if water quality (as reflected by temperature, dissolved oxygen, $\mathrm{pH}$, total suspended solids, and bacterial abundances) is correlated with the sale price of single-family properties sold between 2005 and 2007 within a 2 mile buffer of Johnson Creek and a 2 mile buffer of Burnt Bridge Creek. We associated 10479 property transactions from 2005 to 2007 in the Johnson Creek study area with dry season water quality at the nearest monitoring site in the year the property was sold. We associated 5093 property transactions that occurred in the Burnt Bridge Creek study area between 2005 and 2007 with dry season water quality at the nearest monitoring site in 2008. We chose to use water quality data from 2008 for the Burnt Bridge Creek study area because of an increase in the number of sites - from 8 in 2007 to 15 in 2008 - and because of the much better spatial distribution of monitoring sites in 2008.

Models included detailed information about each property's structural (lot square footage, building square footage, etc.), location (median income at the census tract level, distance to central business district, etc.), and environmental variables (percentage of property in floodplain, slope, land cover, etc.); neighborhood fixed effects were used in the Burnt Bridge Creek model and quadrant fixed effects in Johnson Creek. We included dummy variables to capture the month and year of property sales. A semi-log function form, the most commonly used specification, was used for both models (Champ et al., 2003), and each model was tested and corrected for spatial correlation. Additional details are provided in Netusil et al. (2014).

Data on governance and policy were collected through 19 semi-structured interviews with public officials and other stakeholders across a range of levels of government and areas of responsibility. Interviews were transcribed and analyzed using Dedoose software 4.10.0. The data were supplemented through a review of state and local government documents and media reports.

\section{Results and discussion}

\subsection{Relationship between water governance and water quality monitoring}

Water quality monitoring has a long history in both Burnt Bridge Creek (Vancouver) and Johnson Creek (Portland), though the characteristics of that monitoring have changed over time (Table 1). Most significantly for the present study, the intensity and purpose of monitoring differs considerably between the two cities despite the uniformity in federal law, such as the Clean Water Act (CWA), and Pacific Northwest political culture. This contrast appears to be due to differences in state and local governance and in the timing and nature of development on the two sides of the Columbia River.

In the 1970s and 1980s, water quality monitoring, as proxied by stream temperature, was more frequent in Burnt Bridge Creek than in Johnson Creek (Fig. 3). This difference reflects the specific concerns of local managers in an area rapidly transitioning from rural to urban development. In the 1970s, Clark County officials working to develop a restoration plan for Vancouver Lake (a floodplain lake within the city of Vancouver, and the terminal catchment for Burnt Bridge Creek) identified septic tank systems in the Burnt Bridge Creek watershed as a major source of contamination (Starr, 1996). Between 1978 and 1995, a Vancouver city program identified nearly 1000 aging septic systems and helped connect them to the city sewer system (Callahan, 1995). The consistent water quality monitoring regime during this period appears to have been motivated by local concerns for human 
Table 1. Characteristics of significant stream water quality monitoring programs in Burnt Bridge Creek and Johnson Creek.

\begin{tabular}{|c|c|c|c|}
\hline Period & Agency & Frequency & Parameters \\
\hline \multicolumn{4}{|c|}{ Burnt Bridge } \\
\hline 2006-present & USGS & $\begin{array}{l}\text { Daily or monthly grab } \\
\text { samples during summer } \\
\text { and fall months, } \\
\text { inconsistent }\end{array}$ & $\begin{array}{l}\text { Alkalinity, } \mathrm{NH}_{3}-\mathrm{N}, \text { ammonia, chloride, } \\
\text { conductivity, DO, fecal coliform, } \\
\text { nitrate-nitrite, ortho-phosphate, } \mathrm{pH}, \\
\text { temperature, TKN, TP, TSS, turbidity }\end{array}$ \\
\hline 1972-2009 & WADE & $\begin{array}{l}\text { Grab quarterly, monthly } \\
\text { samples, inconsistent }\end{array}$ & $\begin{array}{l}\text { Temperature, conductivity, } \mathrm{pH}, \mathrm{DO}, \\
\text { fecal coliform, chloride, TSS, turbidity, } \\
\text { ammonia, dissolved organic carbon, } \\
\text { nitrate/nitrite, total nitrogen, } \\
\text { orthophosphate, TP, total organic carbon, } \\
\text { chlorophyll } a\end{array}$ \\
\hline 2008-2009 & WADE & $\begin{array}{l}\text { Continuous daily during } \\
\text { summer and fall months }\end{array}$ & $\begin{array}{l}\text { Temperature, conductivity, pH, DO, } \\
\text { fecal coliform, chloride, TSS, turbidity, } \\
\text { alkalinity, ammonia, dissolved organic } \\
\text { carbon, nitrate/nitrite, total persulfate } \\
\text { nitrogen, orthophosphate, TP, total } \\
\text { organic carbon, chlorophyll } a\end{array}$ \\
\hline 1990-1998 & $\begin{array}{l}\text { City of } \\
\text { Vancouver } \\
\text { with SWHD }\end{array}$ & $\begin{array}{l}\text { Monthly during summer } \\
\text { and fall months }\end{array}$ & $\begin{array}{l}\text { Temperature, fecal coliform, DO, } \mathrm{pH} \text {, } \\
\text { nitrogen, } \mathrm{TP}\end{array}$ \\
\hline 2004-2005 & $\begin{array}{l}\text { City of } \\
\text { Vancouver } \\
\text { (WRPP) }\end{array}$ & $\begin{array}{l}\text { Monthly during summer } \\
\text { and fall months }\end{array}$ & $\begin{array}{l}\text { Temperature, fecal coliform, DO, } \mathrm{pH} \text {, } \\
\text { nitrogen, } \mathrm{TP}\end{array}$ \\
\hline 2006-2007 & $\begin{array}{l}\text { City of } \\
\text { Vancouver }\end{array}$ & $\begin{array}{l}\text { Daily during summer } \\
\text { and fall months }\end{array}$ & $\begin{array}{l}\text { Temperature, fecal coliform, DO, } \mathrm{pH} \text {, } \\
\text { nitrogen, TP }\end{array}$ \\
\hline \multicolumn{4}{|c|}{ Johnson } \\
\hline 1998-present & USGS & $\begin{array}{l}\text { Continuous sub-daily, } \\
\text { daily around the year }\end{array}$ & Temperature, TSS \\
\hline 1972-present & ORDEQ & $\begin{array}{l}\text { Monthly or quarterly } \\
\text { samples }\end{array}$ & $\begin{array}{l}\text { Temperature, conductivity, } \mathrm{pH}, \mathrm{DO}, \\
\text { TP, N, alkalinity, hardness, chloride, } \\
\text { color, BOD, COD, potassium, fecal } \\
\text { coliform, sulfate, total coliform, TS, TSS }\end{array}$ \\
\hline 1996-present & $\begin{array}{l}\text { City of } \\
\text { Portland }\end{array}$ & $\begin{array}{l}\text { Monthly grab samples } \\
\text { for designated stations } \\
\text { from 1996-2010. } \\
\text { Stations moved around } \\
\text { since } 2011\end{array}$ & $\begin{array}{l}\text { Temperature, conductivity, pH, DO, } \\
\text { turbidity, TSS, BOD, ortho phosphate, } \\
\text { nitrogen-nitrate, E-coli, chromium, } \\
\text { copper, lead, zinc, hardness }\end{array}$ \\
\hline 1999-present & $\begin{array}{l}\text { City of } \\
\text { Gresham }\end{array}$ & $\begin{array}{l}\text { Inconsistent in earlier } \\
\text { years, } 4 \text { fixed sites and } \\
\text { other stations that move } \\
\text { around, monthly grab } \\
\text { samples }\end{array}$ & $\begin{array}{l}\text { Temperature, conductivity, } \mathrm{pH}, \mathrm{DO}, \\
\text { turbidity, chloride, } \mathrm{BOD}, \mathrm{TSS}, \mathrm{NH}_{3}-\mathrm{N}, \\
\text { chlorophyll } a, \mathrm{NO}_{3}-\mathrm{N}, \mathrm{O}-\mathrm{PO}_{4}, \mathrm{TKN}, \mathrm{TP}, \\
\text { hardness, } \mathrm{Hg}, \mathrm{Cd}, \mathrm{Cu}, \mathrm{Pb}, \mathrm{Ni}, \mathrm{Zn}, \mathrm{E}-\text { coli, } \\
\text { PCBs, } \mathrm{PAH} \text {, pesticide, diesel, gasoline, } \\
\text { hydrocarbon }\end{array}$ \\
\hline 2010-present & $\begin{array}{l}\text { Oregon } \\
\text { Department } \\
\text { of Agriculture } \\
\text { and the East } \\
\text { Multnomah } \\
\text { soil and water } \\
\text { conservation }\end{array}$ & $\begin{array}{l}7 \text { sites, monthly grab } \\
\text { samples in the Upper } \\
\text { Johnson Creek, } \\
\text { continous sub-daily } \\
\text { monitoring for two sites } \\
\text { each summer }\end{array}$ & $\begin{array}{l}\text { Turbidity, } \mathrm{pH} \text {, total dissolved solids } \\
\text { conductivity, E.coli nitrate, phosphorous } \\
\text { total suspended solids }\end{array}$ \\
\hline 2009-present & $\begin{array}{l}\text { The inter- } \\
\text { jurisdictional } \\
\text { commitee }\end{array}$ & $\begin{array}{l}\text { Sub-daily at } 15 \text { to } 45 \text { sites } \\
\text { throughout the } \\
\text { watershed, depending on } \\
\text { the year }\end{array}$ & Temperature \\
\hline
\end{tabular}

SWHD = Southwest Washington Health District; WADE = Washington Department of Ecology; USGS = US Geological Survey; $\mathrm{ORDEQ}=$ Oregon Department of Environmental Quality; WRPP = Water Resources Protection Program 


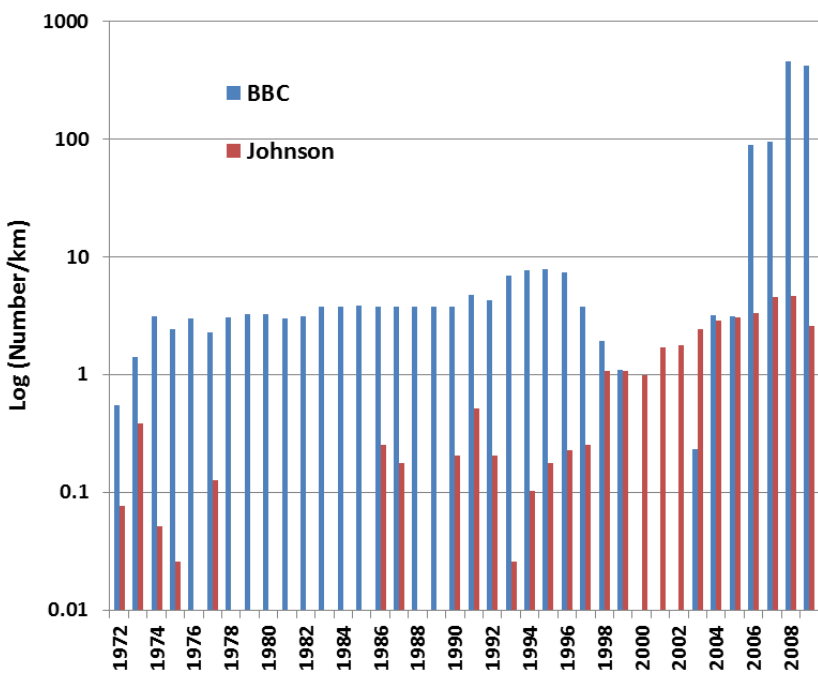

Fig. 3. Annual frequency of stream temperature monitoring normalized by stream length $(\mathrm{km})$ in Burnt Bridge Creek and Johnson Creek. Frequency per stream length is log transformed.

health and recreation, as also indicated by the involvement of the state health department in monitoring (Table 1).

In the 1990s, both streams were listed as "impaired waters" under section 303(d) of the federal Clean Water Act. Johnson Creek was added to the list by the Oregon Department of Environmental Quality (ODEQ) in 1998 and its total maximum daily loads (TMDLs) were approved by the US Environmental Protection Agency in 2006. The Washington Department of Ecology (WADE) added Burnt Bridge Creek to the CWA 303(d) list in 1996, but the TMDLs are still under development.

The much longer time frame between 303(d) listing and TMDL approval in Burnt Bridge Creek is indicative of a more litigious and contentious governance process in Vancouver, WA, a process that has affected the quantity and purpose of stream monitoring. For some time WADE had been pressuring Vancouver and Clark County officials to work to restore the creek to a condition fit for swimming and fishing (Callahan, 1995). Stakeholders reported in interviews, however, that local officials argued that Burnt Bridge Creek was now an urban stream and that restoration to pre-urban conditions was impractical. Water quality monitoring in Burnt Bridge Creek actually declined in the years following the 303(d) listing, the opposite of the response in Portland's Johnson Creek (Fig. 3) when Portland's Bureau of Environmental Services started regular stream monitoring in the late 1990s, followed by the City of Gresham in the early 2000s.

Public participation in the political and legal process also drives water quality monitoring in Vancouver. The City of Vancouver reinitiated monitoring efforts in 2004 after a 6-year gap and increased those efforts in 2006 (Table 1, Fig. 3). This appears to have been partly in response to citizen complaints and a CWA lawsuit filed in 2004 by a neighborhood association and a local environmental organization. The plaintiffs and the City of Vancouver settled the lawsuit in a signed agreement approved by the city council in May of 2006 (Mize, 2006). In the document, Vancouver agreed, among other things, to "develop and implement a long term water quality monitoring program to generate data regarding water quality in Burnt Bridge Creek" (City of Vancouver, Rosemere Neighborhood Assoc. and Clark Co. Nat. Res. Council, 2006). A further increase in monitoring in 2008 and 2009 reflected WADE's intensified efforts to develop the TMDLs for Burnt Bridge Creek (WADE, 2008, 2011). The City of Vancouver closed down its monitoring program during the WADE TMDL study (Table 1). City staff reported that this was a cost saving measure made possible because WADE's monitoring was sufficient.

While not directly related to changes in monitoring regimes, another citizen-initiated lawsuit further exemplifies the importance of contentious litigation in shaping water governance in the Washington part of the metropolitan area. In December 2013, Clark County officials agreed to pay USD 3.6 million to settle a CWA lawsuit. Significantly, this money must be spent on water quality improvement projects within the county, but it will be administered by the Lower Columbia Fish Recovery Board, a regional body with representation from local governments, native tribes and citizen activists. In other words, litigation has been used to greatly expand the number and diversity of institutional stakeholders with a voice in local water governance (Rice, 2011, 2013).

Today, water quality monitoring in Vancouver is still primarily driven by issues of legal compliance and is constrained by budgetary limitations. Even advocates of monitoring for other purposes recognize the importance of these external regulatory drivers. As a Vancouver city government technician put it, "The budget constraints mean that we are doing essentials only ... The state and federal mandates may be hammers but they also justify the funds."

The CWA has been an important driver of water quality governance in Portland as well, particularly with regard to violations stemming from storm water runoff and combined sewer overflows. In 1991, with amendment in 1994, the ODEQ reached an agreement with the City of Portland Bureau of Environmental Services to allow innovative and experimental initiatives such as downspout disconnect programs and the construction of green street infrastructure to be part of management efforts, in addition to conventional pipe replacement and the construction of an ambitious 6 mile-long connecting tunnel that conveys sewage and stormwater (East Side Big Pipe, 2011). In 2011, ODEQ commended Portland for meeting all milestones and requirements of the agreement (Pendersen, 2011).

This emphasis on local innovation and experimentation in Portland, with state-level approval, has had an impact on water quality monitoring and on environmental conditions such as fish habitat in urban streams (Yeakley and Hughes, 2014). For example, regular meetings between governmental 
agencies and citizen stakeholders with interests in Johnson Creek during the early 1990s precipitated the creation of the Johnson Creek Watershed Council (JCWC) in 1995, which coincided with the statewide establishment of watershed councils and the development of the Oregon Plan for Salmon and Watersheds. The Oregon Plan emphasizes voluntary stream restoration and the tight linkage between longterm watershed health, the local economy, and quality of life (Johnson Creek Watershed Council, 2013; Molina, 2014). As such, JCWC shows an exemplary case of the coupled human and water system through active stream restoration and monitoring (Riley, 1998). Johnson Creek's interjurisdictional committee, which represents numerous federal, state, local governmental agencies and non-governmental organizations including JCWC, has been meeting monthly for 20 years, working together closely to help improve stream health.

Interviewees also reported robust budgets for monitoring in Portland. Interviews and public documents showed an emphasis on the value of monitoring as an applied science to inform adaptive management. In 2010 the city established the Portland Area Watershed Monitoring and Assessment Program (PAWMAP) using protocols developed by the EPA's Environmental Monitoring and Assessment Program. The goal of the PAWMAP was to go beyond compliance "to consistently track and communicate progress under the PWMP (Portland Watershed Management Plan), guide discussions about targets for improvement in local watersheds, and illustrate what investments or activities make the most difference for rivers and streams" (City of Portland, 2011). One indication of Portland's commitment to monitoring beyond the requirements of compliance may be seen in the continued high level of monitoring after the EPA's approval of Johnson Creek TMDLs in 2006 (Fig. 3).

To summarize our findings for question 1 , we found that governance has a significant impact on water quality monitoring. Monitoring in both streams is heavily influenced by regulatory mandates, but differences in governance were reflected in differences in the quantity and purpose of monitoring. In Vancouver, monitoring is largely done for the purpose of compliance with state and federal legal requirements and in response to citizen complaints and lawsuits. Legal action, state intervention and budgetary constraints have led to fluctuations in the quantity of monitoring in Burnt Bridge Creek, becoming consistently robust only after litigation by local citizen groups and intervention by a state environmental agency (Fig. 3 and Table 1).

In Portland, while compliance with legal mandates is a driver as well, water quality monitoring is increasingly viewed as a tool for understanding what does and does not work to improve water quality and ecosystem health. In Johnson Creek, intentional planning and adaptive management appear to have played greater roles. A multiplicity of federal, state and local agencies have also been directly involved in monitoring, as have citizen organizations. Both creeks now have watershed councils, but the JCWC appears to be more active and has a history of citizen monitoring dating back to the mid-1980s.

The most immediate result of all of these differences in water governance between Portland and Vancouver is the more rapid development and approval of TMDLs for Johnson Creek. These differences in governance can also be seen in other areas of environmental governance such as land use planning. The significance of these two different state policy environments, two different regional governance structures, and two different urban regimes has been investigated further by Thiers et al. (2014) and Kline et al. (2014).

\subsection{Watershed land development, riparian vegetation and stream temperature}

Both Vancouver, WA and Portland, OR (and the entire PVCMSA) have been subject to rapid population growth and development pressure since the 1970s. Land use management has been an explicit goal of urban governance for more than three decades. Land use policy for most of this time, however, was not done to explicitly protect water quality. Rather, it was aimed at the containment of urban growth to preserve forest and farm land. Both cities established urban growth boundaries for this purpose, though differences in state law and local politics caused the Vancouver boundary to be implemented later and expanded more frequently than Portland's boundary (Kline et al., 2014; Thiers et al., 2014).

It is well known that increasing urban land cover, which increases impervious surface areas, is associated with changing seasonal hydrology and water quality (Paul and Meyer, 2001; Chang, 2007; Wang and Cai, 2010). However, no consensus exists regarding which spatial scale is more influential in determining water quality conditions. While some studies have identified watershed-wide land cover as a more important factor than riparian land cover in affecting water temperature (e.g., Scott et al., 2002), others report the opposite case (e.g., Cunningham et al., 2010; Yu et al., 2013). Since more than half of both the Johnson Creek and Burnt Bridge Creek watersheds are already urbanized, and further land development pressure exists (Fig. 4), identifying target areas for environmental conservation has been a prime concern in both Portland and Vancouver. Since riparian canopy cover is one of the most significant physical variables controlling a stream's heat budget (Caissie, 2006; Chang and Psaris, 2013), restoring riparian vegetation has been used as an important strategy in stream restoration (Roth et al., 2010), particularly in Burnt Bridge Creek where less land is available for conservation.

Changes in riparian areas included both losses in woody and unmanaged vegetated areas due to development pressure and gains due to both restoration activities and natural growth of existing vegetation. Riparian areas showed consistent losses during the earlier period (1990-2002) for both cities, with greater losses in unmanaged vegetation for Vancouver and in woody vegetation for Portland (Fig. 4). In the 


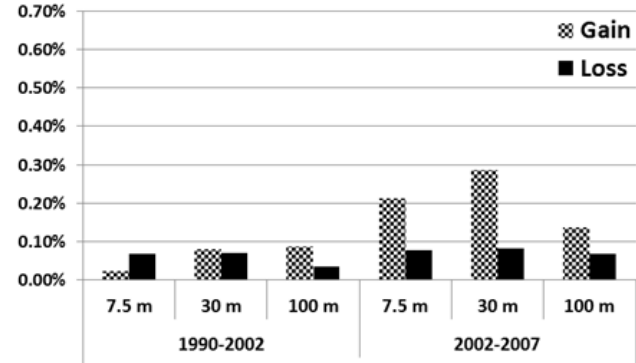

(a)

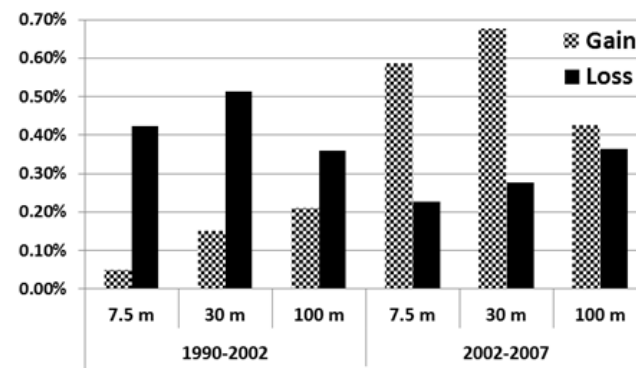

(c)

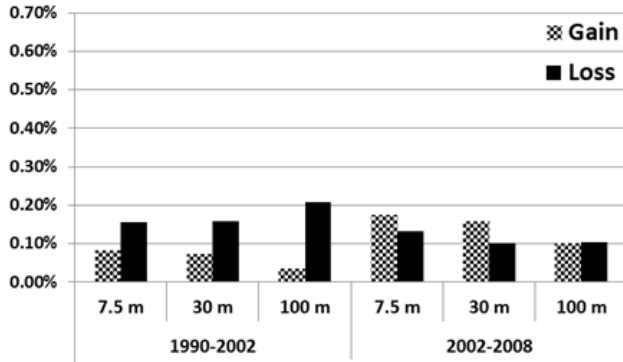

(b) Portland Adjacent Woody Vegetation

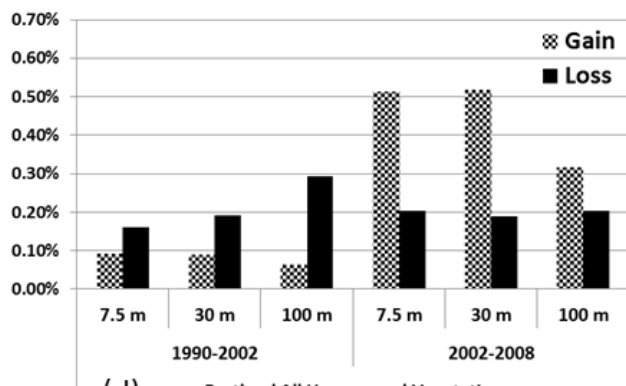

(d)

Fig. 4. Riparian area changes for Portland and Vancouver during the period 1990-2008. Shown are three buffer widths (7.5, 30, 100 m) for each of the two categories of riparian vegetation: (a), (b) adjacent woody vegetation, i.e., contiguous patches of tree and shrub vegetation connected to stream; (c), (d) all unmanaged vegetation, i.e., all vegetated riparian areas within the buffer, whether connected to stream or not. Methods of analysis follow Ozawa and Yeakley (2007).

more recent period (2002-2007 for Vancouver and 20022008 for Portland), there were significant increases in riparian gains for both woody and unmanaged vegetation classes for both cities (Fig. 4). In both cities, gains in riparian area outpaced losses in the latter period for the 7.5 and $15 \mathrm{~m}$ buffer widths. A general observation is that, while Portland and Vancouver have varying riparian management policies, both cities achieved success in conserving and restoring green spaces that are critical to the maintenance of water quality (Levell and Chang, 2008).

At the whole watershed scale, urban land cover is the dominant land cover and increased by 31 and $21 \%$ in BBC and JC, respectively, between 1992 and 2006 (Fig. 5). This urban expansion occurred at the expense of both agricultural and forest land cover. In particular, agricultural and forest lands shrank to 3 and $1 \%$, respectively, of the Burnt Bridge Creek watershed between 1992 and 2006. In the Johnson Creek watershed, agricultural and forest lands each remained at approximately $15 \%$ of the total land cover in 2006. The rapid increase in urban land cover in the Burnt Bridge Creek watershed is attributed to the fact that almost all areas of the watershed reside within the city limits of Vancouver. By contrast, a significant portion of the Johnson Creek watershed remains outside of the urban growth boundary, and is composed of agricultural lands or forests or rural residential areas.

When changes in land cover at the whole watershed scale and the buffer scale are associated with changes in water temperature, there is no clear relationship between the two. As shown in Fig. 6, there are no substantial changes in dry season (May to October) water temperature from the 1990s to the 2000s in either watershed. While Johnson Creek has a similar range of water temperature in both the 1990s and the 2000s, Burnt Bridge Creek has a slightly higher range of water temperature in the 2000s than in the 1990s. This is likely due to a more intense sampling in the late 2000s following the lawsuit discussed above.

Considering that urban areas have expanded more than $20 \%$ in both watersheds during the study period, it is notable that stream temperature did not degrade significantly. In this regard, both cities have protected water quality to some extent by directly protecting and restoring riparian areas. Moreover, Portland included a land use planning approach that kept most headwater source regions outside of the urban growth boundary. Even though the policy mechanisms employed differed across the two watersheds, the outcomes of environmental management, in this case maintaining healthy stream conditions, do not differ in a statistically significant way.

\subsection{Perception: relationship between property sale prices and water quality}

Numerous studies have found a relationship between the sale price of single-family residential properties and water quality (Gibbs et al., 2002; Laggett and Bockstael, 2000; Poor et al., 2007; Bin and Czajkowski, 2013). Water quality parameters 
Table 2. Estimated effect on property sale price from a change in water quality parameter for Johnson Creek (significance for a 1-tail test, $10 \%$ level; values marked "NS" are not statistically significant).

\begin{tabular}{llllll}
\hline Water quality parameter & Study area & $1 / 4$ mile & $1 / 2$ mile & 1 mile & $>1$ mile \\
\hline Fecal coliform & Burnt Bridge & $-3.81 \% \mathrm{NS}$ & $-3.26 \%$ & $-3.67 \%$ & $-1.57 \% \mathrm{NS}$ \\
E-coli & Johnson & $-2.57 \%$ & $-0.84 \%$ & $-1.14 \%$ & $-0.69 \%$ \\
$(100$ count per $100 \mathrm{~mL}$ increase $)$ & & & & & \\
pH $(0.5$ unit increase) & Burnt Bridge & $4.35 \% \mathrm{NS}$ & $-11.56 \%$ & $-9.51 \%$ & $-12.86 \%$ \\
& Johnson & $-4.83 \% \mathrm{NS}$ & $-0.77 \% \mathrm{NS}$ & $-0.81 \% \mathrm{NS}$ & $6.18 \%$ \\
TSS $\left(1 \mathrm{mg} \mathrm{L}^{-1}\right.$ increase $)$ & Burnt Bridge & $-0.78 \% \mathrm{NS}$ & $-0.97 \%$ & $-0.07 \% \mathrm{NS}$ & $0.18^{\mathrm{NS}}$ \\
& Johnson & $1.55 \%{ }^{\mathrm{NS}}$ & $1.73 \%$ & $0.71 \%$ & $-0.05^{\mathrm{NS}}$ \\
Temperature $\left(1^{\circ} \mathrm{C}\right.$ increase $)$ & Burnt Bridge & $-4.92 \% \mathrm{NS}$ & $0.14 \% \mathrm{NS}$ & $1.63 \% \mathrm{NS}$ & $1.51 \% \mathrm{NS}$ \\
& Johnson & $-0.52 \% \mathrm{NS}$ & $-1.42 \% \mathrm{NS}$ & $-1.31 \% \mathrm{NS}$ & $-4.46 \%$ \\
DO $(1 \mathrm{mg} \mathrm{L}-1$ increase $)$ & Burnt Bridge & $1.23 \% \mathrm{NS}$ & $4.49 \%$ & $2.95 \%$ & $3.17 \%$ \\
& Johnson & $13.71 \%$ & $7.05 \%$ & $8.18 \%$ & $3.12 \%$ \\
\hline
\end{tabular}

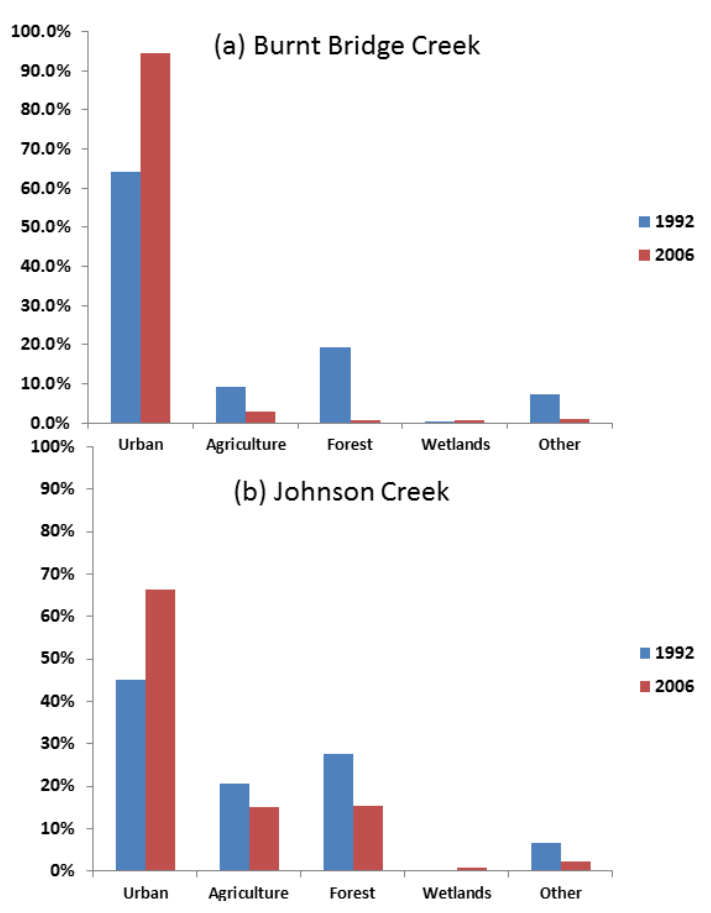

Fig. 5. Change in land cover distribution from 1992 to 2006 in (a) Burnt Bridge Creek and (b) Johnson Creek.

that were most likely to be perceived by residents were selected for our analysis. For example, total suspended solids (TSS) affects water clarity; dissolved oxygen (DO), temperature and $\mathrm{pH}$ may impact fish and wildlife populations; and $E$. coli or fecal coliform concentration may produce foul odors. A priori we expected that increases in E. coli (in Johnson Creek) or fecal coliform concentration (in Burnt Bridge Creek), TSS, and water temperature would have a negative effect on sale price, while increases in DO would have a positive effect. The sign on $\mathrm{pH}$ that would elicit an effect is uncertain, since $\mathrm{pH}$ levels that are either too high or too low can have a negative impact on fish and wildlife (Lease et al., 2003). We believe that perceptions of water quality, rather than knowledge about the water quality measurements themselves, affect the sale price of single-family residential properties near Johnson Creek and Burnt Bridge Creek, and that estimated impacts will vary based on a property's distance from each creek.

Table 2 presents a summary of findings for Johnson Creek and for Burnt Bridge Creek. The results for E. coli in Johnson Creek are statistically and economically significant, with estimated effects from a $100^{\circ} \mathrm{E}$. coli per $\mathrm{mL}$ increase ranging from $-2.57 \%$ for properties within $1 / 4$ mile of Johnson Creek to $-0.69 \%$ for properties located more than 1 mile from the creek. Increases in fecal coliform had a negative effect on sale prices in Burnt Bridge Creek with estimated effects from a 100 colony count per $100 \mathrm{~mL}$ increase of $-3.26 \%$ for properties located between $1 / 4$ and $1 / 2$ mile of the creek and $-3.67 \%$ for properties within $1 / 2$ to 1 mile of the creek. $\mathrm{pH}$ had a large and significantly negative estimated impact on the sale price of properties in the $1 / 2$ mile, 1 mile and greater than 1 mile buffers from Burnt Bridge Creek. Algae blooms in Vancouver Lake, which were correlated with $\mathrm{pH}$ levels (amongst other environmental variables), may explain this result (Lee et al., 2014). DO results were negative and statistically significant for seven of the eight buffers in the study areas, but the estimated effects were generally larger in Johnson Creek. This may be a result of the presence of listed species such as Steelhead and Coho Salmon in Johnson Creek and a demonstrated willingness of residents in the Johnson Creek area to pay for programs that improve fish and wildlife habitat (Larson and Lach, 2008).

The lack of significance for some water quality parameters may be due to multicollinearity, which increases standard errors and reduces t-statistics. Including all of the water quality parameters is preferred to running separate regressions 
(a) Burnt Bridge Creek

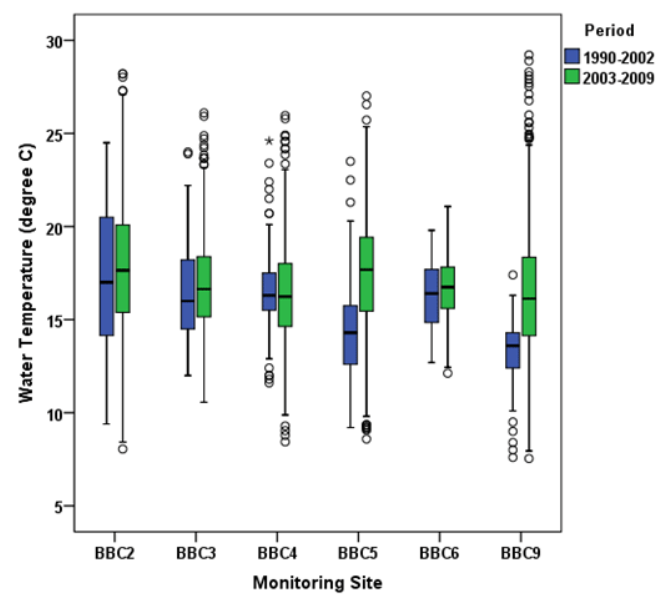

(b) Johnson Creek

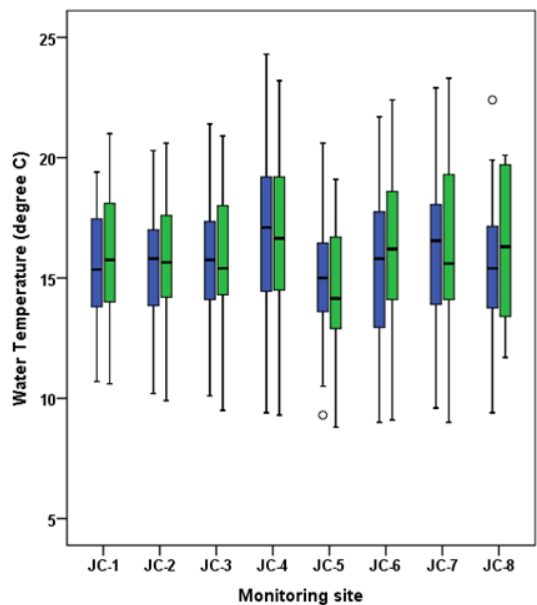

Fig. 6. Dry season (May to October) water temperature for each monitoring site during the 1990s and 2000s in (a) Burnt Bridge Creek and (b) Johnson Creek: sample size varies.

because of concerns about omitted variable bias, which produces inaccurate estimated coefficients. Additional information about the model, tests and corrections for spatial correlation, and policy implications are in Netusil et al. (2014).

\section{Conclusions}

Using a CHANS framework in sociohydrology, we investigated the potential interactions and feedbacks between environmental governance and water quality. Our analyses show the following results. First, water governance affected stream monitoring regimes in both watersheds, but the effects of different monitoring efforts on stream health, as indicated by stream temperature that were included in TMDL standards, was not different across the two watersheds within the time frame of this study. Second, both watersheds experienced rapid urban growth in the past two decades; however, through varying institutional policies, riparian vegetation cover increased in both cities, and the headwaters of Johnson Creek were protected through exclusion from the urban growth boundary. As a result, both cities were able to maintain ambient stream temperature regardless of ongoing urban development. Third, there was a strong feedback in human perception on water quality as indicated by the relationship between water quality and the sale price of single-family residential properties.

Our finding that federal regulatory mandates in response to common water quality characteristics (303 (d) listing) led to very different governance responses at the local level (i.e., differences in the development of TMDLs; differences in changes in monitoring effort) has implications for environmental policy. This finding would tend to support Gibbs and Jonas' (2000, p. 304) argument that as "national environmental narratives enter the local policy arena they are renarrated." The significance of different policy environments and political regimes in the interpretation of federal and state policy at the local level is the subject of another investigation (Thiers et al., 2014). For the present study, these findings imply that federal policymakers and regulators should consider that local government responses to the detection of impaired water quality are complex and may vary greatly from one jurisdiction to another. Regulatory efforts designed to anticipate these different responses may reduce implementation deficit in some locations and take fuller advantage of willingness to go beyond mandates in others.

While our analysis shows some evidence of a plausible effect of water quality on human perception, as reflected in property sales prices, a further study is needed to investigate the dynamic feedbacks in the coupled human-water system that relate to whether changes in home sale prices influence management efforts to improve water quality. A possible feedback might exist, such as riparian management through tax revenue and whether such a tax collecting system is reflected in property values. Addressing such feedbacks in the empirical estimation of the value of water quality and in predicting future management efforts or land use changes will be a next step towards further refining a coupled model illustrated in Fig. 1.

Additionally, further studies are needed to uncover the dynamics of changing environmental governance and water quality at multiple levels. A survey of residents' perceptions about water quality and governance has been collected and is currently being analyzed by other researchers. Analysis of these survey data may provide additional insights into how human perceptions and environmental governance regimes differ across the two watersheds. Additionally, since most urban streams typically exhibit legacy effects from past anthropogenic activities, it is important to trace land development 
policy and its impacts on land surface hydrology from historical geographic perspectives. Related to this is a need to continue stream monitoring to be able to detect any future changes in water quality as they relate to changes in land development patterns and policy. It may be that differences in governance will have more significant impacts on water quality over longer time periods. Finally, since there are multiple pathways to improve ambient water quality, it is necessary to assess potential tradeoffs among different management strategies such as point source control by big pipes or a waste water treatment plant, semi-distributed riparian vegetation cover creation, and installation of green infrastructure. Assessing these tradeoffs may help to inform policymakers as they consider the economic and political transaction costs associated with different ways to manage water quality.

Acknowledgements. The US National Science Foundation funded this study through the Portland-Vancouver ULTRA-Ex grant (grant \# 0948983). Additional support was provided by Portland State University, Oregon State University, Washington State University, and Reed College. The Portland Bureau of Environmental Services and Clark County Environmental Services provided stream water quality data. We also appreciate the Johnson Creek Watershed Council, Portland Metro, and Clark County for sharing GIS data. We also thank Anna Denisse Fisher de Leon and Bethany Pratt at Portland State University and Maya Jarrad, Michael Kincaid, Zachary Levin, Cameron Nilles, and Alex Walker at Reed College for their help with statistical and GIS data analysis. The manuscript was greatly improved by the constructive comments of three anonymous reviewers. Views expressed are our own and are not those of the sponsoring agencies.

Edited by: V. Srinivasan

\section{References}

Abbot, C., Howe, D. A., and Adler, S.: Planning the Oregon way: a twenty year evaluation. Oregon State Univ. Press, Corvallis, OR, 1994.

Allen, J. D.: Stream ecology: Structure and function of running waters, Chapman \& Hall, New York, 1995.

Bin, O. and Czajkowski, J.: The Impact of Technical and Nontechnical Measures of Water Quality on Coastal Waterfront Property Values in South Florida, Mar. Resour. Econ., 28, 43-63, 2013.

Boeder, M. and Chang, H.: Multi-scale analysis of oxygen demand trends in an urbanizing Oregon watershed, J. Environ. Manage., 87, 567-581, 2008.

Caissie, D.: The thermal regime of rivers: a review, Freshwater Biol., 51, 1389-1406, 2006.

Callahan, L.: Bad water in Burnt Bridge, The Columbian, Vancouver, WA, 4 December 1995.

Champ, P. A., Boyle, K. J., and Brown, T. C. (Eds.): A Primer on Nonmarket Valuation, Springer, Norwell, MA, 2003.
Chang, H.: Streamflow characteristics in urbanizing basins in the Portland Metropolitan Area, OR, USA, Hydrol. Process., 21, 211-222, 2007.

Chang, H. and Lawler, K.: Impacts of climate variability and change on water temperature in an urbanizing Oregon basin, in: Water Quality: Current Trends and Expected Climate Change Impacts, IAHS Publ., 348, 123-128, 2011.

Chang, H. and Psaris, M.: Local landscape predictors of maximum stream temperature and thermal sensitivity in the Columbia River basin, USA, Sci. Tot. Environ., 461-462, 587-600, 2013.

Chowdhury, R., Larson, K., Grove, J. M., Polsky, C., Cook, E., Onsted, J., and Ogden, L.: A multi-scalar approach to theorizing socio-ecological dynamics of urban residential landscapes, Cities Environ., 4, 6, 2011.

City of Portland, Bureau of Environ. Services: Portland watershed management plan, www.portlandoregon.gov/bes/article/338860 (last access: 20 May 2013), 2011.

City of Vancouver, Rosemere Neighborhood Assoc. and Clark Co. Nat. Res. Council: Settlement reached in local Clean Water Act case, Approved joint public statement, Vancouver, WA, 2006.

Cunningham, M. A., Menking, K. M., Gillikin, D. P., Smith, K. C., Freimuth, C. P., Belli, S. L., Pregnall, A. M., Schlessman, M. A., and Batur, P.: Influence of Open Space on Water Quality in an Urban Stream, Phys. Geogr., 31, 336-356, 2010.

East Side Big Pipe: Portland Bureau of Environmental Services, available at: http://www.portlandoregon.gov/bes/article/201984 (last access: 18 May 2013), 2011.

Fischel, W. A. The Homevoter Hypothesis: how home values influence local government taxation, school finance, and land-use policies, Harvard University Press, Cambridge, MA, 2005.

Gibbs, D. and Jonas, A.: Governance and Regulation in Local Environmental Policy: the Utility of a Regime Approach, Geoforum, 31, 299-313, 2000.

Gibbs, J. P., Halstead, J. M., Huang, J. C., and Boyle, K. J.: An hedonic analysis of the effects of lake water clarity on New Hampshire lakefront properties, Agr. Resour. Econ. Rev., 31, 39-46, 2002.

Hoyer, W. and Chang, H.: Development of Future Land Cover Change Scenarios in the Metropolitan Fringe, Oregon, USA with Stakeholder Involvement, Land, 3, 322-341, 2014.

Johnson Creek Watershed Council: What is a watershed Council?, http://jcwc.org/what-is-a-watershed-council/, last access: 22 December 2013.

Kline, J. D., Thiers, P., Ozawa, C. P., Yeakley, J. A., and Gordon, S.: Examining land use planning outcomes in the Portland, metropolitan area under contrasting planning regimes, OR - Vancouver, WA, USA, in review, 2014.

Laggett, C. G. and Bockstael, N. E., Evidence of the effects of water quality on residential land prices, J. Environ. Econ. Manage., 39, 121-144, 2000.

Larson, K. L. and Lach, D.: Participants and non-participants of place-based groups: an assessment of attitudes and implications for public participation in water resource management, J. Environ. Manage., 88, 817-830, 2008.

Lease, H. M., Hansen, J. A., Bergman, H. L., and Meyer, J. S.. Structural changes in gills of Lost River suckers exposed to elevated $\mathrm{pH}$ and ammonia concentrations, Compara. Biochem. Physiol. C, 134, 491-500, 2003. 
Lee, T. A., Rollwagen-Bollens, G. C., and Bollens, S. M.: The influence of water quality variables on cyanobacteria blooms and phytoplankton community composition in a shallow temperate lake, Lake Reservoir Manage., in review, 2014.

Leggett, C. G. and Bockstael, N. E.: Evidence of the effects of water quality on residential land prices, J. Environ. Econ. Manage., 39, 121-144, 2000.

Levell, A. and Chang, H.: Monitoring the Channel Process of a Stream Restoration Project in an Urbanizing Watershed: A Case Study of Kelley Creek, Oregon, USA, River Res. Appl., 24, 169$182,2008$.

Liu, J., Dietz, T., Carpenter, S., Alberti, M., Folke, C., Moran, E., Pell, A., Deadman, P., Kratz, T., Lubcheno, J., Ostrom, E., Ouyang, Z., Provencher, W., Redman, C., Schneider, S., and Taylor, W.: Complexity of coupled human and natural systems, Science, 317, 1513-1516, 2007.

McConnell, W. J., Millington, J. D. A., Reo, N. J., Alberti, M., Asbjornsen, H., Baker, L. A., Brozovic, N., Drinkwater, L. E., Drzyzga, S. A., Fragoso, J., Holland, D. S., Jantz, C. A., Kohler, T. A., Maschner, H. D. G., Monticino, M., Podesta, G., Pontius, R. G., and Redman, C. L.: Research on coupled human and natural systems (CHANS): approach, challenges, and strategies, Bull. Ecol. Soc. Am., 92, 218-228, 2011.

Mize, J.: Suit over storm water settled, C3, The Columbian, Vancouver, WA, 12 May 2006.

Molina, N. M.: Regulatory and Planning Approaches to Protecting Salmonids in an Urbanizing Environment, in: Wild Salmonids in the Urbanizing Pacific Northwest, edited by: Yeakley, J. A., Mass-Hebner, K. G., Hughes, R. M., Springer, New York, 1129, 2014.

Netusil, N., Kincaid, M., and Chang, H.: Valuing Water Quality in Urban Watersheds: A Comparative Analysis of Johnson Creek, Oregon and Burnt Bridge Creek, Washington, in review, 2014.

Ozawa, C. P. and Yeakley, J. A.: Performance of management strategies in the protection of riparian vegetation in three Oregon cities, J. Environ. Plan. Manage., 50, 803-822, 2007.

Pataki, D., Boone, C. G., Hogue, T. S., Jenerette, G. D., McFadden, J. P., and Pincetl, S.: Socio-ecohydrology and the urban water challenge, Ecohydrology, 4, 341-347, 2011.

Paul, M. J. and Meyer, J. L.: Streams in the urban landscape, Ann. Rev. Ecol. Systemat., 32, 333-365, 2001.

Pendersen, D.: Oregon Department of Environmental Quality Memorandum to the Environmental Quality Commission, Oregon Department of Environmental Quality, Salem, OR, 28 January 2011.

Poor, P. J., Pessagno, K. L., and Paul, R. W.: Exploring the hedonic value of ambient water quality: a local watershed-based study, Ecol. Econ., 60, 797-806, 2007.

Pratt, B. and Chang, H.: Effects of Land Cover, Topography, and Built Structure on Seasonal Water Quality at Multiple Spatial Scales, J. Haz. Mat., 209/210, 48-58, 2012.

Rice, S.: Stormwater Ruling Puts Restriction on County, The Columbian, Vancouver, WA, 29 December 2011.

Rice, S.: Clark County to Pau \$3.6 Million for Violating Clean Water Act, The Columbian, Vancouver, WA, 18 December 2013.
Riley, A.: Restoring Streams in Cities: A Guide for Planners, Policy Makers, and Citizens, Island Press, Covelo, CA, 1998.

Roth, T. R., Westhoff, M. C., Huwald, H., Huff, J. A., Rubin, J. F., Barrenetxea, G., Vetterli, M., Parriaux, A., Selkeer, J. S., and Parlange, M. B.: Stream temperature response to three riparian vegetation scenarios by use of a distributed temperature validated model, Environ. Sci. Technol., 44, 2072-2078, 2010.

Scott, M. C., Helfman, G. S., McTammany, M. E., Benfield, E. F., and Bolstad, P. V.: Multiscale influences on physical and chemical stream conditions across Blue Ridge landscapes, J. Am. Water Resour. Assoc. 38, 1379-1392, 2002.

Sivapalan, M., Savenije, H., Bloeschl, G.: Sociohydrology: A new science of people and water, Hydrol. Process. 26, 1270-1276, 2012.

Starr, L.: This week in Clark County history, The Columbian, Vancouver, WA, 24 October 1996.

Thiers, P., Stephan, M., Walker, A., and Gordon, S.: Differences in regime and structure within an ecological region: comparing environmental governance in the Portland-Vancouver metropolitan area, in review, 2014.

USGS - US Geological Survey: Multi-Resolution Land Characteristics Consortium 2012, available at: http://www.mrlc.gov/ (last access: 13 March 2013), 2012.

Wang, D. and Cai, X.: Comparative study of climate and human impacts on seasonal baseflow in urban and agricultural watersheds, Geophys. Res. Lett. 37, L06406, doi:10.1029/2009GL041879, 2010.

WADE - Washington Department of Ecology, Quality Assurance Project Plan: Burnt Bridge Creek Fecal Coliform Bacteria, Dissolved Oxygen, and Temperature Total Maximum Daily LoadWater Quality Study Design, available at: https://fortress.wa.gov/ ecy/publications/publications/0803110.pdf (last access: 12 October 2012), 2008

WADE - Washington Department of Ecology, Water Quality Improvement Project: Burnt Bridge Creek Area, available at: http://www.ecy.wa.gov/programs/wq/tmdl/burntbridge/ BurntBrTMDLpfv.pdf (last access: 13 November 2012), 2011.

Yeakley, J.A: Water Quality in Pacific Northwest Urban and Urbanizing Aquatic Ecosystems, in: Wild Salmonids in the Urbanizing Pacific Northwest, edited by: Yeakley, J. A., Mass-Hebner, K. G., Hughes, R. M., Springer, New York, 101-121, 2014.

Yeakley, J. A. and Hughes, R. M.: Global and Regional Context of Salmonids in Urban Areas, in: Wild Salmonids in the Urbanizing Pacific Northwest, edited by: Yeakley, J. A., Mass-Hebner, K. G., Hughes, R. M., Springer, New York, 11-29, 2014.

Yeakley, J. A., Ozawa, C. P., Fisher de Leon, A. D., and Armstrong, C. M.: Gains and losses of urban riparian greenspaces in Portland-Vancouver, AWRA 2012 Summer Specialty Conference, Riparian Ecosystems IV: Advancing Science, Economics and Policy, Denver, CO, 1-5, 2012

Yu, D. Y., Shi, P. J., Liu, Y. P., and Xun, B.: Detecting land use-water quality relationships from the viewpoint of ecological restoration in an urban area, Ecol. Eng., 53, 205-216, 2013. 